\title{
РЕЦЕНЗІї
}

УДК $811.16 ’ 374$

Т. А. Космеда

\section{НОВЫЙ УЧЕБНЫЙ СЛОВАРЬ}

(Kozdra M., Dubiczynski W. Dydaktyczny słownik tematyczny rosyjsko-polskich paraleli leksykalnych. Leksyka kulinarna (rzeczownik). Warszawa: Wydawnictwo Uniwersytetu Warszawskiego, 2019. 202 s. / Коздра М., Дубичинский В. Учебный тематический словарь русско-польских лексических параллелей. Кулинарная лексика (имена существительные). Warszawa: Wydawnictwo Uniwersytetu Warszawskiego, 2019. 202 c.)

Лексикограф, создаюший двуязычньй словарь, как бы прокладывает огромное множество путей - дорог, дорожек и тропок - между двумя народами. От того, как точно проложены им эти дороги, дорожки и тропки, зависит, правильно ли пойдут многие тысячи поверивших ему путников...

(В. Берков)

В каждом образованном обществе особенно трепетно относятся к справочной литературе - энциклопедиям, различного рода словарям, в частности к толковым лексиконам, из которых пользователь получает информацию о значении слов и устойчивых выражений. Чрезвычайно важны в период активных межъязыковых связей переводные словари, в частности учебного типа. Именно к подобной разновидности лексикографической продукции относится рецензируемый словарь.

Работа над составлением учебного словаря требует от его составителей и глубоких знаний лексикографической теории, и опыта работы над составлением словарей, и опыта преподавания иностранных языков, совершенного владения языками, которые стали объектом лексикографической обработки.

Авторский тандем Михал Коздра и Владимир Дубичинский - это идеальный союз теории и практики, поскольку на счету у В. Дубичинского и солидные теоретические труды по лексикографии (Дубичинский, 1993; Дубичинский, 2009; Дубичинский, 2017; Дубичинский \& 
Ройтер, 2015; Дубичинский \& Ройтер, 2017 и др.), и конкретные рекомендации для практической реализации лексикографической теории (Дубичинский, 1994а; Дубичинский, 19946 и др.), и опыт преподавания русского языка в иноязычной аудитории, а М. Коздра - польский русист, научный работник Варшавского университета, методист, преподаватель русского языка как иностранного, имеющий богатый опыт дидактической работы в студенческой аудитории и научные публикации, освещающие проблемы двуязычной лексикографии (Коздра, 2018; Коздра, 2017).

Словарь состоит из Предисловия (Przedsłowia), зеркально отражающего информацию, изложенную на польском и русском языках. Предисловие состоит также из двух частей: в первой части предлагаются описание методологических основ словаря, детально объясняется теория лексических параллелей, длительное время разрабатываемая В. Дубичинским; вторая часть словаря под названием «Общие сведения об Учебном тематическом словаре русско-польских лексических параллелей» состоит из 6 параграфов и представляет собой четкую структуру: 1. Целевая аудитория; 2. Отбор слов; 3. Толкование и иллюстративные словосочетания; 4. Разновидности лексических параллелей с выделением нескольких подпунктов (4.1. Полные лексические параллели; 4.2. Неполные лексические параллели; 4.3. Ложные лексические параллели); 5. Омонимы и паронимы в словарных статьях; 6. Построение словарной статьи. Даже перечень параграфов и подпунктов, как видим, свидетельствует о прозрачности методологической исследовательской базы и учете сложных случаев системного описания с проекцией на межъязыковое восприятие.

После предисловия следует библиография (Коздра \& Дубичинский, 2019: 35-37), состоящая из:

a) перечня источников - тематических русско-польских и польско-русских словарей, а также из толково-переводных русско-польских и польско-русских словарей, созданных в конце XX - начале XXI веков, разного типа и объема (так называемые «большие» однои двуязычные толковые словари, лексические минимумы, идеографические словари, лексиконы заимствованных слов, синонимов, использован и словарь пищевой метафоры);

б) интернет-источники (Национальный фотокорпус польского языка; Национальный корпус русского языка; электронные варианты 
толковых словарей польского и русского языков; новый частотный словарь русского языка; видеоблоги; кулинарные программы и телешоу /«Смак», «Домашняя кухня»/; сайты российских ресторанов и кафе /«Кулинарная лавка Братьев Караваевых», «Кофе Хауз»/; сайты супермаркетов / «Ашан», «Перекресток»/);

в) научная литература, где указаны в основном авторские труды, написанные на русском и польском языках: эти публикации свидетельствуют, что составлению словаря предшествовала большая работа по апробации отдельных положений теории лексических параллелей, что очень похвально; здесь же названы и другие важные для концепции словаря и его наполнения научные разыскания, авторами которых являются M. Kuratczyk, I. Łukaszuk, К. Кусаль, В. Лейчик, Э. Секежицки, Л. Малаховский, Т. Шкапенко.

Библиография, как видим, свидетельствует о скрупулезности составителей словаря, их тщательности, соответствии современному подходу к подбору словарного материала.

Далее авторы предлагают удачную, на наш взгляд, схему словарной статьи (Коздра \& Дубичинский, 2019: 40), представленную графически с использованием цветового разнообразия для характеристики принципиально важных параметров, что делает эту схему более доступной для восприятия, а также перечень условных знаков и помет (Коздра \& Дубичинский, 2019: 41-42), позволяющих легко: определять тип лексических параллелей, обращать внимание на процессы, характерные для трансформаций лексического значения (сужение, расширение), различать типы значений (интерсемема, идиосемема). Здесь же представлены буквенные сокращения метаязыковых обозначений словарной статьи (стилистические, грамматические и др. пометы).

Алфавитный список описанных лексико-семантических групп позволит пользователю словаря лучше в нем ориентироваться. Отметим также, что в пределах тематической группы «Кулинария» составители предлагают 16 лексико-семантических групп на базе имен существительных - «Блюда», «Выпечка», «Грибы», «Зерновые продукты и злаки», «Молочные продукты», «Мясо и колбасы», «Напитки», «Овощи, фрукты, растения, орехи, приправы, специи, пряности» (последняя из названных группа представляется несколько неоднородной, возможно, следовало разграничить перечисленные микросистемы). 
В тематическую группу «Кулинария» включены и названия посуды, кроме этого, не совсем удачной представляется название лексико-семантической группы «Ресторан», куда входят не только лексемы, связанные с названиями заведений общественного питания, номинации их функциональных частей, но и слова, называющие виды сервиса, названия периодов приема пищи и даже виды напитков (коктейль). Возможно, эту лексико-семантическую группу более целесообразно назвать «Типы заведений общественного питания и сервис, с ними связанный». Не совсем удачной представляется и рубрика «Другие», куда входят лексемы типа аппетит, аромат, вонь, голод, готовка, деликатес и т. д. Очевидно, эти слова можно было также распределить по микросистемам, например, запахи, эмоции и чувства, связанные с процессом питания и приготовлением пищи, и под.

После алфавитного списка лексико-семантических групп следует словарный тезаурус (Коздра \& Дубичинский, 2019: 45-57) и собственно словарь (Коздра \& Дубичинский, 2019: 61-156). Он содержит необходимую и важную информацию, описанную в предисловии, позволяющую не только ознакомиться со значением слова, типами его эквивалентов, так называемых параллелей, но и с омонимами, паронимами не только в пределах одного языка, но и межъязыковых.

Завершают словарь упражнения и задания (Коздра \& Дубичинский, 2019: 157-158), что оправдывает жанр лексикона как учебного словаря, хотя упражнений и заданий могло быть и больше, а также русско-польский (Коздра \& Дубичинский, 2019: 159-180) и польско-русский (Коздра \& Дубичинский, 2019: 181-201) алфавитные указатели.

Анализ словаря позволяет утверждать, что это новаторский лексикон, жанр которого можно определить как комплексный, тематический, аспектуальный (раскрыта тема «Кулинария»с описанием лексико-грамматического класса существительных, распределенных по лексико-семантическим группам), толково-переводной словарь учебного типа.

Словарь очень удачно построен, он важен для учебной деятельности и является «помощником» не только для тех, кто обучается, но и для тех, кто преподает, обучает, ибо подробно описаны сложные случаи восприятия значений з учетом всех «подводных камней».

Однако предела совершенству нет. Возможно, было бы целесообразно расширить параметры словарных пометок, учитывая 
и явление взаимодействия и взаимовлияния русского и польского языков, например, лексема петрушка (Коздра \& Дубичинский, 2019: 121) пришла в русский язык из языка польского через украинский, а слово чайник (Коздра \& Дубичинский, 2019: 131), естественно, русского происхождения. Можно было бы расширить и систему заданий, предложив пользователям словаря выделить слова, заимствованные в русский язык из польского языка и наоборот. Желательно было бы указывать наличие дублетных ударений, например, в слове творог (Коздра \& Дубичинский, 2019: 95) ударение стоит на первом слоге, но в этом слове оно параллельное, поэтому ударным может быть и первый, и второй слоги, а в односложных словах, очевидно, нет смысла ставить ударения, как, например, в лексеме сыр (Коздра \& Дубичинский, 2019: 95).

К сожалению, составители не учли работ известного польского русиста Ежи Калишана, посвященные проблеме омонимии в русском языке (Kaliszan, 1997; Kaliszan, 2017), а также не использовали его словарь русских омонимов (Kaliszan, 2015).

Думаем, что рецензируемый словарь настолько удачен и полезен в учебном процессе, имеет столько достоинств, что его необходимо будет переиздавать, попутно, очевидно, можно будет вносить и некоторые изменения для его совершенствования.

Видимо, принципы составления этого словаря можно актуализировать и в украинской учебной лексикографии, пополнив учебную литературу для тех, кто изучает украинский язык как иностранный.

\section{ЛИТЕРАТУРА}

1. Дубичинский В. Основы словаря лексических параллелей русского и польского языков. Język rosyjski XXI wieku. Żródła i perspektywy / red. G. Mańkowska, M. Kuratczuk, D. Muszynka-Wolny, J. Wasiluk. Warszawa, 2017. S. 165-176. 2. Дубичинский В. В. Искусство создания словарей. Конспекты по лексикографии. Харьков: ХПУ, 1994 (а). 102 c. 3. Дубичинский В. В. Лексикографические заметки. Рекомендации создателям словарей. Харьков: ХГПУ, 1994 (б). 70 с. 4. Дубичинский В. В. Лексикография русского языка: учеб. пособ. (для вузов). Москва: Флинта: Наука, 2009. 432 с. 5. Дубичинский В. В. Лексические параллели. Харьков, 1993. 155 с. 6. Дубичинский В., Ройтер Т. Уточнения к определению лексических параллелей. Слово и словарь. Vocabulum et vocabularium: сб. науч. материалов / гл. ред. И. Л. Копылов. Минск, 2017. С. 353-358. 7. Дубичинский В., Ройтер Т. Теория и лексикографическое описание лексических параллелей: моногр. Харьков: Підручник НТУ “ХПI", 2015. 147 с. 8. Коздра М. Особенности словарных статей в «Русско-польском словаре лексических параллелей». Językoznawstwo: prace na XVI Międzynarodowy Kongres Sławistów w Bielgradzie / red. 
Z. Greń. Poznań, 2018. S. 139-145. 9. Коздра М. Принципы лексикографирования в Русско-польском словаре лексических параллелей. Internacional Scientific Journal Philology. 2017. № 1 (7). С. 95-100. 10. Kaliszan J. Омонимия производных слов в русском языке. Poznań: Wydawnictwo Naukowe UAM, 1997. 144 с. 11. Kaliszan J. Русские омографы. Poznań: Wydawnictwo Naukowe UAM, 2017. 180 s. 12. Kaliszan J. Словарь омографов русского языка. Poznań: Wydawnictwo Naukowe UAM, 2015. 196 s.

\section{REFERENCES}

1. Dubichinskij, V. (2017). Osnovy slovarya leksicheskix parallelej russkogo i pol'skogo yazykov [The basics of the dictionary of lexical parallels of the Russian and Polish languages]. Język rosyjski XXI wieku. Żródła i perspektywy - 21st century Russian language. Sources and perspectives. (pp. 165-176). Warszawa [in Russian]. 2. Dubichinskij, V. V. (1994a). Iskusstvo sozdaniya slovarej. Konspekty po leksikografii [The art of creating dictionaries. Lexicography Summaries]. Xar'kov: XPU [in Russian]. 3. Dubichinskij, V. V. (1994b). Leksikograficheskie zametki. Rekomendacii sozdatelyam slovarej [Lexicographic notes. Recommendations to the creators of dictionaries]. Xar'kov: XGPU [in Russian]. 4. Dubichinskij, V. V. (2009). Leksikografiya russkogo yazyka [Lexicography of the Russian language]. Moskva: Flinta: Nauka [in Russian]. 5. Dubichinskij, V. V. (1993). Leksicheskie paralleli [Lexical Parallels]. Xar'kov [in Russian]. 6. Dubichinskij, V. \& Rojter, T. (2017). Utochneniya k opredeleniyu leksicheskix parallelej [Refinements to the definition of lexical parallels]. Slovo i slovar'. Vocabulum et vocabularium - Word and Dictionary. Vocabulum et vocabularium. (pp. 353-358). Minsk [in Russian]. 7. Dubichinskij, V. \& Rojter, T. (2015). Teoriya i leksikograficheskoe opisanie leksicheskix parallelej [Theory and lexicographic description of lexical parallels]. Xar'kov: Pidruchnik NTU "XPI" [in Russian]. 8. Kozdra, M. (2018). Osobennosti slovarnyx statej $\mathrm{v}$ «Russko-pol'skom slovare leksicheskix parallelej». Językoznawstwo - Linguistics, 139-145 [in Russian]. 9. Kozdra, M. (2017). Principy leksikografirovaniya v Russko-pol'skom slovare leksicheskix parallelej [The principles of lexicography in the Russian-Polish dictionary of lexical parallels]. Internacional Scientific Journal Philology, 1 (7), (pp. 95-100) [in Russian]. 10. Kaliszan, J. (1997). Omonimiya proizvodnyx slov v russkom yazyke [Homonymy of derivative words in Russian]. Poznań: Wydawnictwo Naukowe UAM [in Russian]. 11. Kaliszan, J. (2017). Russkie omografy [Russian homographs]. Poznań: Wydawnictwo Naukowe UAM [in Russian]. 12. Kaliszan, J. (2015). Slovar' omografov russkogo yazyka [Dictionary of Russian homographs]. Poznań: Wydawnictwo Naukowe UAM [in Russian].

Космеда Тетяна Анатоліївна - доктор філологічних наук, професор, завідувач кафедри україністики Інституту російської й української філології, Університет імені Адама Міцкевича в Познані (Польща); 61-874 Poznan, Al. Niepodległości 4.

Tel.: +38-050-516-82-11

E-mail: tkosmeda@gmail.com

https://orcid.org/0000-0001-8912-2888

Kosmeda Tetiana - Doctor of Philology, Professor, Head of the Ukrainian Studies Department, Institute of Russian Philology and Ukrainian Philology, Adam Mitskevych University; Al. Niepodległości 4, Poznań, 61-874, Poland.

Надійшла до редакції 18 грудня 2019 року 